\title{
Deák József: Az orosz és a magyar rendészeti sajtó kezdetei
}

\begin{abstract}
Absztrakt
A rendészeti sajtó kialakulásának, szerepének, hazai és nemzetközi története a rendészet állami feladataiból, jellemzöiböl adódóan sok közös vonással, tanulsággal rendelkezik. Különbözöségek ugyan adódnak az egyes államok történelmi fejlödésének különféleségeiböl, de a rendészeti szervek és külsö-belsö kommunikációjuk feladatrendszerének azonos fejlödési szakaszai az állam berendezkedésétől, nagyságától, földrajzi elhelyezkedésétöl függetlenül, szintén sok rokon jellemzöt, akár máig szóló tapasztalatot rejtenek.
\end{abstract}

\section{Abstract}

The formation, role, domestic and international history of the law enforcement press has many common features and edification, due to the state's tasks and characteristics of the police. There are differences in the several historical development of individual states, but the same stages of development of the task system of law enforcement agencies and their external-internal communication are independent from the state, size and geographical location, which are hiding also many related features, even the experience of today.

\section{Az orosz-magyar kapcsolatok történelmi gyökerei}

Az orosz-magyar politikai, ezen belül rendészeti kapcsolatok alakulása az 184849 szabadságharc, az I. majd a II. világháború alatt és azt követő, negatív sztereotípiái jól ismertek. E kapcsolatok, főként politikai kezdeteinek, a messzi régmúltból sarjadó pozitív vonatkozásai viszont kevésbé ismertek. Bakonyi István, az Orosz nyelv, kultúra és mentalitás magyar szemmel címü, orosz nyelven publikált tanulmánya is említ néhány példát erre. ${ }^{235} \mathrm{Az}$ István király ellen pogány lázadást szervező Vazul három fia közül kettő a Kijevi Ruszban talált menedékre. Közülük András, 1046-ban tért haza, és immár királyként a Kijevi Nagyfejedelemséget vezető, Bölcs Jaroszláv lányát, Anasztáziát vette feleségül.

A két állam kapcsolatának különösen érdekes szakasza kezdődött a XVIII. század elején, I. (Nagy) Péter cár és II. Rákóczi Ferenc erdélyi fejedelem, majd a haza szabadságáért összeszövetkezett magyar rendek vezérlő fejedelme között, 1707-ben született megállapodással. Az 1703-ban indított Rákóczi-szabadságharcban 1707-re már az egész ország felszabadult a Habsburg uralom alól, amikor ki is kiáltották a Habsburg ház trónfosztását. Ekkor fordult Rákóczi orosz támogatásért a cárhoz, aki a maga részéről 20 ezer katonát ígért is cserébe azért, ha Rákóczi a továbbiakban elfoglalja a lengyel trónt. A cári ígéret a svédekkel és a törökökkel vívott háborúja miatt sem teljesült, de szövetsége Rákóczival az ő háborús hatalmi pozícióit is erősítette. E

\footnotetext{
${ }^{235}$ BAKONYI István: Русский язык, культура и менталитет глазами венгров. Obrazozványie i nauka 2013/2 121-132. https://cyberleninka.ru/article/v/russkiy-yazyk-kultura-i-mentalitet-glazami-vengrov
} 
szerződéssel a két állam közötti ismét baráti kapcsolatok létesültek; nagyköveteket, udvari képviselőket, fontos politikai információkat cseréltek, szabaddá vált a két ország között az alattvalók költözése és az árukereskedelem.

A szabadságharc leverése után Rákóczi egy ideig Oroszországban reménykedett az ígért cári segítségben. A rendszeres gazdasági kapcsolatok a két ország között Rákóczival kezdődtek, például ekkortól indultak rendszeres borszállítmányok Oroszországba. A magyar bort I. Péter is nagyon kedvelte, az orosz udvar pedig különösen nagyra értékelte. Annyira, hogy 1774-ig orosz kincstári szőlőbirtokok virágoztak Magyarországon, Szentpéterváron pedig, 1732 és 1798 között egy úgynevezett Tokaji Bizottság müködött.

A magyar nép kedvence volt József nádor felesége, Alexandra Pavlovna, II. Katalin orosz cárnő unokája, I. Pál leánya, akivel 1799-ben házasodott össze. A városépítő-szépítő nádor legföbb tanácsadója felesége volt, aki Bécs szépségétől lenyügözve javasolta férjének, hogy Pest belvárosát szintén ruházzák fel Európa fővárosait jellemző vonásokkal. De nem csak városépítő kezdeményezésével örökítette magát a magyar történelembe Alexandra Pavlovna, a francia trikolór mintájára magyar nemzeti zászlót tervező nádornak a fehér és a piros mellé az ő javaslatára került a zöld szín. A nádorfeleség tragikusan rövid élete alatt a más népek kultúrájára fogékony előszeretettel hordta a korabeli arisztokrata feleségek által megvetett színes magyar népviseletet, és előszeretettel tanulmányozta a helyi népszokásokat. Neki köszönhetően csendült fel a fényüző szalonokban az egyszerü emberek ropogós csárdása. Kereste az alkalmakat a velük való beszélgetésre, bőkezủen támogatva a betegeket, rászorulókat.

Az 1848-49-es magyar szabadságharc elfojtásában az osztrák császárral kötött megállapodás alapján részt vállaló orosz csapatok emberséggel bántak a fogságba esett magyar szabadságharcos tisztekkel, katonákkal, szemben az ellenség osztrák seregeinél megismertekkel. Magyarország és Oroszország egyaránt Kelet-Európában található. Történelmében pedig egyaránt fellelhetők a kelet-európai társadalmi megkésett fejlődés jellemzői, az eltérések lényegében legfeljebb a két nemzet nyelvének, kultúrájának, az államok kialakulása történetének, e fejlődés tempójának különbözőségeiből adódnak. Ezért a két állam rendészettörténete a rendészeti lapjaik kialakulása is hordoz közös európai vonásokat.

\section{A magyar rendőri lapok forrásvidéke}

A rendőrségi sajtó, a rendőri lapok történelmi előzményeinek feltárásához ${ }^{236}$ a 19. század elejéig, az első nyomtatott körözési értesítők megjelenéséig kell visszanyúlnunk. ${ }^{237}$ A körözések kötelezően tartalmazták a körözött személy nevét és személyleírását, valamint a büncselekményt, amelynek elkövetésével alaposan gyanúsítható volt a feltételezett (s ezért körözött) tettes. Alapos gyanú hiányában körözés nem volt közzé tehető. ${ }^{238} \mathrm{Az}$ adatok nyilvánosságra hozatala persze a privát

\footnotetext{
${ }^{236}$ DEÁK József: Negyedszázados fennállásukat ünneplö tudományos társaságok. Nemzetbiztonsági Szemle (online) (eISSN: 2064-3756) 3 évfolyam 4. szám. 2015. pp. 101-109.

${ }^{237}$ DEÁK József: A polgári magyar állam (1867-1944) rendvédelmi sajtója. In: PARÁDI Á. (szerk.): Ünnepi tanulmányok Parádi József 65. születésnapja tiszteletére. Szemere Bertalan Magyar Rendvédelemtörténeti Tudományos Társaság. Budapest. pp. 65-88.

${ }^{238}$ KovÁCS István: Die Ermittlung der Förderung der geschäftsmäßigen Prostitution. Hadtudományi Szemle, 2015/3. szám, pp. 177-185. Vö.: Szempontjukból fontos, hogy az információáramlás gördülékeny, rugalmas, és pontos legyen.” In: KOVÁCS István: The enforcement of crime prevention duties of the Police, in relation of youth - especially juvenile prostitution - and thepractical experiment in Hungary. Hadtudományi Szemle, VIII. évfolyam, (2015) 1. szám, pp. 231-245.
} 
szféra határának átlépését jelentette. ${ }^{239} \mathrm{~A}$ magyar Rendőri lapok e körözőlevelek magyarországi reprezentánsa. Ha megnézzük, a lap rovatai szinte teljesen megegyeznek a hannoveri rendőri lapok rovataival: Felkutatandó személyek, intézkedések, eltünt személyek, lopott és jogellenesen használt tárgyak, elveszett úti okmányok, letöltött büntetések, kiutasítottak (nálunk kitoloncoltatottak), közveszélyes, csavargók, előállítandó személyek. ${ }^{240}$

A rendészeti szervek összlétszáma a vizsgált időszakban mindvégig néhány tízezer főnyi volt. Ekkora létszámot időben tájékoztatni a legfontosabb jogszabályváltozásokról, ${ }^{241}$ gondoskodni továbbképzésükről, eljuttatni hozzájuk a rendőri, csendőri, pénzügyőri társasági élet híreit nagy szervezettséget, sok munkát igénylö feladat, aminek ellátására már érdemes volt létrehozni az egyes szervezeteken belüli sajtót. A rendészeti kommunikáció néhány sajátossága ismeretében megállapítható, hogy a speciális rendészeti tevékenységek esetében mindenképp fontos és szükséges egy vagy több olyan szervezeten belüli ${ }^{242}$ akár miniszteriális szintü kiadvány, orgánum, amely a fentebbemlítetteken kívül erösíti a szervezet kohézióját, valamint a szervezeti kultúra egyik színtereként funkcionál. ${ }^{243}$

„A rendészeti kommunikáció az emberi kommunikációnak sajátos területe. „A kommunikációs eljárások differentia specificáját (nevezhetjük a közlésfolyamatban felmerülő zajoknak) a következők okozzák:

a) a rendészeti tevékenység hivatás, amelynek képviselői különös felelösséggel és komoly hatalommal felruházva; ${ }^{244}$

b) az emberek közötti konfliktusok közepette végzik problémamegoldó munkájukat;

c) legtöbbször a nyilvánosság különös érdeklődésétől kísérve;

d) egy sajátos szervezeti kultúra tagjaként, amelynek fö jellemzője a szigorú hierarchia, ${ }^{245}$ valamint a parancsuralmi rendszer, ${ }^{246}$ és amelyben

e) a merev jogi, katonai, hivatalos stílus az uralkodó, mindamellett

f) el kell fogadtatni a közösséggel e szervezetek erőszak-monopóliumi és szankcionáló szerepét, ráadásul úgy, hogy

g) annak tagjait együttmüködésre bírjuk, és meggyőzzük őket a biztonságteremtő munkaszolgáltató és polgárbarát jellegéről."247

${ }^{239}$ KovÁCS István: Prostitúció, és prohibíció a mai Magyarországon: avagy miért nem sikerül a rendőrségnek a szocializmust levetközni a XXI. században. Létünk, (2018/2.), pp. 7-29.

240 KRISKÓ, Edina: A rendörség társadalmi rendeltetése és a rendörségi kommunikáció.http://nydi.btk.pte.hu/sites/nydi.btk.pte.hu/files/pdf/Krisko_Edina2013 disszertacio.pdf, Letöltés ideje: 2019. 04. 28.

${ }^{241}$ KovÁCs István: „Olajozás”, szervezett bünözés és prostitúció a 90-es években Magyarországon. Nemzetbiztonsági Szemle, (2015/1.), pp. 114-146.

242 Vö.: „Alapvető funkciója az értékek és érdekek védelme, az érdekek érvényre juttatásának támogatása." In: KovÁCS István: Is the prostitution a threatdanger to a country's (national)security? Nemzetbiztonsági Szemle, V. évfolyam (2017) különszám, pp. 12-24.

${ }^{243}$ Vö.: „A néptől kapott legitim állami hatalom monopóliumával ellátva társadalmi rendeltetésüket maximálisan elláthassák. In: KovÁcs István: Vezetési funkciók egy helyi rendvédelmi szerv életében. Ellenörzés, mint a kiadott szabályok, és utasitások betartásának (kontroll)feladata. Államtudományi Mühelytanulmányok, II. évfolyam, (2017) 21. szám, pp. 1-30.

${ }^{244}$ KovÁCs István: A reglementációs prostitúció és az emberi méltóság kapcsolata, különös tekintettel egy alkotmánybírósági határozatra. Belügyi Szemle, 2016/b/2. szám, 109-126.

${ }^{245}$ KovÁCs István: Vezetési funkciók egy helyi rendvédelmi szerv életében. Tervezés, mint az elérendö cél, és az ahhoz elvezetö tevékenységek meghatározásának folyamata. Müszaki katonai Közlöny, (2018/3), 196.

${ }^{246}$ KovÁcs István: Vezetési stílusok a hivatásos állomány szemével.BARÁTH Emőke (szerk.): Rendészettudomány a fiatal kutatók szemével konferenciakötet. 2019. pp. 169-179. 


\section{A cári orosz sajtó és belügyi kiadványok színrelépése}

Oroszországban 1703 óta jelenik meg rendszeresen sajtótermék. ${ }^{248} \mathrm{Ez}$ nagyobbrészt, a meglehetősen rapszódikusan megjelenő gyüjteményes kiadványsor. Ezeknek csak kis része jelenik meg szigorú rendszerességgel. Újságot, a mai formájában akkoriban egyáltalán nem adtak ki.

Könyvek és más nyomdatermékek kiadása Oroszországban mindig kizárólagos állami elöjog volt, amit az egyéb sajtótermékekkel kapcsolatos tradícionális állami bizalmatlanság kísért. Csak 1783-ban egy speciális rendelet oldotta fel a nyomdatermékek kiadásának állami monopóliumát, engedélyezve a városi rendőri szerv elözetes cenzúrájával magánkiadásokat is.

I. Sándor 1802 szeptemberében egy kiáltvány aláírásával hozta létre a minisztériumokat, innen számítják Oroszország Belügyminisztériumának (OBM) létezését is. ${ }^{249}$

„A minisztérium több mint két évszázados történelme során mindig jelentős figyelmet szentelt a rendészeti rendszer müködése kommunikációs feltételei biztosításának. A példás társadalmi rend fenntartásáért kifejtett erőfeszítésekre, a gyilkosok, tolvajok, rablók megbüntetésére vonatkozó említésekkel találkozhatunk, az orosz állam fennállásának, különféle időszakainak periodikáiban. Főként a társadalmi támogatottság elnyerésére, hogy sikerüljön pozitív képet kialakítani a törvényesség őréről, noha akkoriban, de manapság szintúgy, gyakran nem népszerü a rendőrségnek érvényt szerezni, akár kényszerítő eszközökkel is, a jogszabályoknak."250

Még két évnek sem kellett eltelnie a minisztériumok megalakításától, amikor 1804. január 27-én megjelent az Orosz birodalom Belügyminisztériumának első hivatalos hatósági kiadványa, a „Szentpétervári folyóirat” első száma. Kiadása az első belügyminiszter, Viktor Pavlovics Kocsubej személyi titkárának, Mihail Mihajlovics Szperanszkíj kezdeményezésére született, aki utóbb az 1809-ig megjelenő folyóirat első szerkesztője volt. Ö írta a havilapban megjelent cikkek zömét. Évről évre nyilvánvalóbbá vált, hogy, hogy pozitív kép a rendőrségről elég hatékonyan segíti az együttmüködés kialakítását, megerösítését a lakossággal és a társadalmi intézményekkel. ${ }^{251}$

Ez persze nem azt jelenti, hogy más országokban, például Nagy Britanniában, Németországban, vagy az Egyesült Államokban a kezdetektől ideális kapcsolat működne a rendészeti szervek és a polgárok között. Például a rendöri szervek tevékenységének alapvető problémája a kényszerítő eszközök alkalmazásának szükségessége.

\footnotetext{
247 SUBA László: $A$ pénzügyőrségi sajtó kezdetei. http://m.ludita.uninke.hu/repozitorium/bitstream/handle/11410/10625/2014_1_tt_subal.pdf?sequence=1\&isAllowed=y (letöltve: 2019. április 28-án)

${ }^{248}$ RumJANCEVA Marina Fedorovna: A XVIII.-XX. század eleji történelmi források /Исторические источники XVIII. - $\quad$ начала XX. http://www.historichka.ru/materials/istochnikovedenie/index.html letöltve: 2019. április 28-án)

${ }^{249}$ Ministry of Internal Affairs of the Russian Federation: 1802-1917 https://xn--b1aew.xn-p1ai/history/1802_1917, (letöltve: 2019. április 28-án)

${ }^{250}$ Ministry of Internal Affairs of the Russian Federation: A kezdetek kezdete (1802-1917) /У начала начал (1802-1917)/ https://mvd.ru/upload/site1/document_file/0NNNIGno3q.pdf (letöltve: 2019. április 28-án)

${ }^{251}$ KovÁCs István: Vezetési funkciók egy helyi rendvédelmi szerv életében. Célmeghatározás, vagyis a feladatok kitüzésének, és tisztázásának folyamata. Rendőrégi Tanulmányok, (2018/3.), pp. 119-136.
} 
Valamilyen fokon az ellentmondás feloldását, pontosabban a probléma élének tompítását, nyugati szociológusok szerint elösegítené, ha a figyelmet nem csak a rendőrtisztképzésre és a társadalommal folytatandó munkára fordítanák, hanem a polgárokat is tanítanák a rendőrséggel történő együttmüködésre.

Hogyan található meg a társadalom elvárásainak megfelelő egyensúlya a kényszerítésnek és a meggyőzés módszereinek? Miként lehet elnyerni a polgárok bizalmát nem a szavak szintjén, hanem a gyakorlatban? Ezek a kérdések régóta foglalkoztatják a világ társadalomtudósait. Még a XIX. század elején, a London rendőrségét megalapító Sir Robert Peel, a brit rendőrség számára írott utasításában rögzítette a témával kapcsolatos alapvető elképzeléseit. Ezek hosszú éveken át egyfajta „Biblia”-ként szolgáltak Nagy Britannia rendőrségi osztályainak a társadalommal folytatandó munka megszervezésében, és jelentős hatással voltak más országok rendőrségeire, egyebek közt Oroszországéra is. Ez az utasítás egyebek közt leszögezi: „Minden rendőrségi munkatársnak szem előtt kell tartania, hogy a polgárok védelme, segítése nem kevésbé fontos kötelességük, mint a bünözök elfogása. Ebböl következik, hogy a bünmegelőzésre és az elkövetők elfogására fordított erőfeszítései során a társadalom szolgájaként és védelmezőjeként kell magára tekintenie, aki minden törvénytisztelö állampolgárhoz, annak társadalmi helyzetétöl függetlenül, változatlan türelemmel, udvariassággal és kedvesen fordul. Ügyesen körültekintö, békés módszerekkel mindig el lehet érni, hogy az emberek betartsák a rendőr utasításait. Mert aki így használja hatalmát, jobban teljesíti rendőri szerepét, mint kollégája, aki a hatalmára túlzottan hagyatkozva, kockáztatja a szembeszegülés kialakulását, ami előbb vagy utóbb felülkerekedik."252

\section{A magyar szabad sajtó és a rendészeti sajtó születése}

A kiegyezéssel ismét szabad lett a magyar sajtó, amely igyekezett a nemzetiségekkel való bánásmódban az abszolutizmus viszonyait konzerválni. 1867. március 17-én életbe lépett a '48-as sajtótörvény (XVIII. t.c.), de Erdélyben örizte hatályát 1871-ig az 1852-es szabályozás, ahogy Horvátországban és Fiumében is. A Határőrvidéken ellenben az osztrák sajtópátens volt érvényben. Az 1875-ig terjedő időszak, mint a legszabadabb magyar sajtókorszak él a történelmi emlékezetben. ${ }^{253}$

Ez a kedvező légkör, minden bizonnyal inspirálta a rendészet belső sajtóorgánumainak létrejöttét is.1869. augusztus 15-én jelenik meg az első magyar rendőri szaklap ${ }^{254}$ „Közbiztonság” cím alatt. Az első szám megjelenése előtt a lap szerkesztősége „Mutatványlapot” adott ki, júliusban tizenhatezer példányban szétküldve azt a hatóságoknak és községeknek.

Ebben a számban a szerkesztő „Nyílt kérelemmel” fordul a magyarországi bünfenyítő vagy közrendészeti üggyel foglalkozó összes tisztviselői karhoz, a fö- és alszolgabírókhoz, tiszti ügyészekhez, városi fö- és alkapitányokhoz, jegyzőkhöz,

\footnotetext{
${ }^{252}$ Ministry of Internal Affairs of the Russian Federation: A kezdetek kezdete (1802-1917) /У начала начал (1802-1917)/ https://mvd.ru/upload/site1/document_file/0NNNIGno3q.pdf (letöltve: 2019. április 28-án)

${ }^{253}$ KRISKÓ Edina: A rendörség társadalmi rendeltetése és a rendőrségi kommunikáció.http://nydi.btk.pte.hu/sites/nydi.btk.pte.hu/files/pdf/Krisko_Edina2013_disszertacio.pdf (letöltve: 2019.április 28-án)

${ }^{254}$ SAllai János: Beköszöntő a Rendörségi Tanulmányok első számához (Rendörségi szakfolyóiratok a „Közbiztonság”-tól napjainkig)http://www.bmtt.hu/rtt/assets/letolt/rt/201801/03_Sallai_Janos_Bekoszonto.pdf (letöltve: 2019. április 28-án)
} 
csendbiztosokhoz és községi jegyzőkhöz. Kéri őket, hogy alkalmanként tájékoztassák a szerkesztőséget érdekesebb rendőri vagy büneseményről, különösen a bűneset elkövetője kiderítésének módjait, valamint munkájukkal kapcsolatos szakcikkeket is vár tapasztalt tisztviselőktől.

Az Országos Széchenyi Könyvtárban és a Rendőrség-történeti Múzeum Könyvtárában megőrzött laprelikviákat és rendőri évkönyvek közül nem egyből már csak egyedi példányok vannak. Legtöbbjük elnevezéséből feltünik a rendőri jelleg: Rendőri Lapok (1882), A rendőr (1913), Rendőrségi Lapok (1914), Magyar Rendőr (1934). kiadtak A Rend (1923) néven napilapot is, mely Anglia után a kontinens unikális kiadványa volt. Egy, a testületen belüli szolgálati ág rangját bizonyítja, hogy külön lap jelent meg Magyar Rendőrkutya néven (1934). A bünügyi detektívek sajtóorgánuma a Detektív (1919), Magyar Detektív (1925) 255

A csecsemőkorát élő magyar csendőrség ${ }^{256}$ eleinte az 1882-ben indult Rendőri Lapok hasábjain kapott nyilvánosságot. E lap közölte a csendőrparancsnokságok hivatalos közleményeit, a törvényellenesen távollevő hadkötelesek és katonaszökevények névsorát, címlapján pedig egy-egy körözött bünöző eredeti fényképe látható. De nem klisé után készült nyomat, hanem felragasztott fénykép. Ez az eljárás a magyar sajtó életében minden valószínüség szerint egyedülálló $\mathrm{s}$ csak nyomozólapnál érthető. 1897-ben a lapnak Magyar Csendőr alcíme volt... 1894 januárjában Nagykanizsán megjelent az első Csendőrségi Közlöny, 1896. január 4-én pedig Esztergomban megszületett az első magyar csendőrújság is, Endrödy Géza csendőr főhadnagy szerkesztésében, Magyar Csendőr címmel. A jó írógárdával rendelkező hetilap azonban, úgy látszik, nem bírta a vidéki levegőt, mert 1897-ben a szerkesztőt már Pesten találjuk a Rendőri Lapoknál s az eddig önálló lapból ott alcím és rovat lett. Nem sokkal később, 1899-ben a Törvényszéki és Rendőri Újság is adott mellékletet Csendőrség címmel s mire elérkezett a századforduló, már volt Csendőr Újság is, mely szak- és általános ismereteket közölt... 1907-ben a Csendőrségi Lapokkal korszerü sajtót kap az akkor már izmosodó magyar csendőrség. A gondosan és hozzáértéssel szerkesztett lap azelőtt, 1882-től 1907-ig Rendőri Lapok címmel élt. 1907-től 1918-ig a belügyminisztérium ${ }^{257}$ kiadásában jelent meg, 1918/19-ben változáson esett át, majd megszünt és 1924-ben mai alakjában Csendőrségi Lapokként kelt újra életre. A mai idő egyetlen katonai folyóirata, mely a háborús ${ }^{258}$ papírkorlátozásig rendszeresen szépirodalmat is adott ${ }^{259} \mathrm{~A}$ Magyar Csendőrség a közbiztonsági szolgálat teljesítésére, a személy- és vagyonbiztonság megóvására, a közcsend, a rend és a biztonság fenntartására létrehozott katonai szervezésü testület Magyarországon. ${ }^{260}$

\footnotetext{
${ }^{255}$ TóTH Sándor: A rendörség krónikásai - 140 év laptörténete. In: SZOMOR S. Jubileumi Emlékalbum a 125 éve alakult budapesti detektívtestület tiszteletére. Budapest, 2011. Országos Rendőr-főkapitányság, pp. 144-145.

${ }^{256}$ DEÁK József: A Magyar Királyi Belügyminisztérium a hátország közbiztonságáért a Nagy Háború idején. Társadalom és honvédelem. 19. évfolyam 4 szám. NKE Szolgáltató Nonprofit Kft. Budapest, 2015. p. 83.

${ }^{257}$ DEÁK József: Military industry and readjustment in the Hungarian hinterland in the First World War. Central European Papers Vol 2. Issue 2. Opavai Sziléziai Egyetem Közpolitikák Kara. Opava, 2014. pp. 23-35.

${ }^{258}$ Immár a II. világháborús - a szerző.

259 http://epa.oszk.hu/00000/00021/00210/pdf/MKSZ_EPA00021_1942_66_03_290-300.pdf Letöltés ideje: 2015.03 .13 .

${ }^{260}$ VEDÓ Attila: A Magyar Királyi Csendörség közbiztonsági tevékenységének szervezete és gyakorlata. In: ORBÓK Ákos (szerk.). A hadtudomány és a XXI. század. Budapest, 2016. Doktoranduszok Országos Szövetsége pp. 361-373.
} 
A gróf Andrássy Gyula miniszterelnök által megalakított kormány egyik legfontosabb embere Lónyay Menyhért pénzügyminiszter, a kiegyezés bonyolult pénzügyi részének kimunkálója, elismert nemzetgazdasági szaktekintély volt. Az ő nevéhez füződik az önálló Magyar Királyi Pénzügyőrség létrehozása, ${ }^{261}$ mely a magyar államkincstár bevételeit biztosító, azaz a gazdasági rendésztünk feladatait kizárólagosan ellátó, ${ }^{262}$ katonailag szervezetten müködő szaktestület volt. Az 1867. március 10-én létrehozott szervezet feladatai között - a pénzügyi törvények és rendszabályok 1868. november 26-án megjelent hivatalos összeállításából kitünően - a csempészet és a pénzügyi törvények és szabályok áthágásának megakadályozása, továbbá a pénzügyi törvények és rendeletek vagy szabályok megszegőinek, az adó- vagy illetékfizetési kötelezettség alól kibúvóknak a felderítése és kézre kerítése szerepelt. Hét esztendővel a magyar pénzügyőrség létrejötte után, 1874. február 1-jén Pécsett megjelent az első testületi szaklap „A pénzügyő” címmel. A 140 éve kiadott első pénzügyőrségi újság - a fejléc tanúsága szerint - „,ismeretterjesztő és szép-irodalmi folyóirat, a m. kir. pénzügyőrség szakközlönye és arcképcsarnoka" volt. Amint a Dobos Nagy János által szerkesztett és kiadott lap első számának bevezetőjében olvashatjuk, már az „ősPénzügyőr”-nek is két fő célja volt: „nem fogunk mi ez irat hasábjain politizálni, személyeskedni, avagy feleselni... hanem a magas szolgálat érdekében: oktatni és mulattatni szándékom..."263

\section{Következtetések}

Az ismertetett rendörségi-rendészeti orosz, illetve magyar és egyéb nemzetközi szaklapok életre hívásának, szerepének példáiból, Markovich Miklós szavaival mi is leszürhetjük: „Szaklapot írni alapjában könnyü. Az író ismeri közönségét, tudja, mi érdekli. Tisztában van az intelligenciájával. Úgy tartalomban, mint formában megfelelőt képes tehát nyújtani. Rendőri szaklapot írni már nehezebb. A rendörség munkaköre szélesen tagozódik. Minden irányban olyan kiterjedt, hogy igazán kiválót, csak a specialisták nyújthatnak. A specialistát azonban csak a saját külön problémái érdeklik. Közönyös minden más kérdéssel szembe, s így írása ritkán tarthat számot általános érdeklődésre." 264

Azonban általános tanulságként leszürhető, hogy a szakma érdekeit, mindig inkább az igényes szaklapok, mint az ezeknél esetleg jóval népszerübb, üzleti érdekek által mozgatott, ezért inkább szenzációgyártásból, mint a valóság hü feltárásából virágzó bulvárlapok szolgálták.

${ }^{261}$ V.ö.: SzABÓ Andrea: A pénzügyi igazgatás szervezete és képzési rendszere a kiegyezéstől az I. világháború végéig. In: CZENE-POLGÁR Viktória - ZsÁMBOKINÉ FICSKOvSZKY Ágnes (szerk.): Mérföldkövek az adó- és vámigazgatás történetéböl. Magyar Rendészettudományi Társaság Vám és Pénzügyöri Tagozata. Budapest, 2017. pp. 124-137.

${ }^{262}$ V.ö.: SzABÓ Andrea: A pénzügyi igazgatás szervezeti keretei egykor és most a rendészeti feladatok tükrében. In: GAÁL Gyula - HAUTZINGER Zoltán (szerk.): Szent Lászlótól a modernkori magyar rendészettudományig. Pécs, 2017. pp. 351-356. és Szabó Andrea: A Magyar Királyi Pénzügyőrség rangrendszere 1867-1947. Rendvédelem-történeti Füzetek. XXVII. évf. 54. szám. pp. 107-126.

263 SUBA László: $A$ pénzügyőrségi sajtó kezdetei. http://m.ludita.uninke.hu/repozitorium/bitstream/handle/11410/10625/2014_1_tt_subal.pdf?sequence=1\&isAllowed=y (letöltve: 2019. április 28-án)

${ }^{264}$ MARKOVICH Miklós: A szaklap problémája. Rendőr, 1927.07.16., p. 1. 


\section{Felhasznált irodalom}

[1] BAKONYI István: Русский язык, культура и менталитет глазами венгров. Obrazozványie i nauka 2013/2 pp. 121-132. https://cyberleninka.ru/article/v/russkiy-yazyk-kultura-i-mentalitet-glazamivengrov

[2] DEÁK József: A Magyar Királyi Belügyminisztérium a hátország közbiztonságáért a Nagy Háború idején. Társadalom és honvédelem. 19. évfolyam 4 szám. NKE Szolgáltató Nonprofit Kft. Budapest, 2015. p. 83.

[3] DEÁK József: A polgári magyar állam (1867-1944) rendvédelmi sajtója. In: PARÁdI Á. (szerk.): Ünnepi tanulmányok Parádi József 65. születésnapja tiszteletére. Szemere Bertalan Magyar Rendvédelem-történeti Tudományos Társaság. Budapest. pp. 65-88.

[4] DEÁK József: Military industry and readjustment in the Hungarian hinterland in the First World War. Central European Papers Vol 2. Issue 2. Opavai Sziléziai Egyetem Közpolitikák Kara. Opava, 2014. pp. 23-35.

[5] DEÁK József: Negyedszázados fennállásukat ünneplö tudományos társaságok. Nemzetbiztonsági Szemle (online) (eISSN: 2064-3756) 3 évfolyam 4. szám. 2015. pp. 101-109.

[6] http://epa.oszk.hu/00000/00021/00210/pdf/MKSZ_EPA00021_1942_66_03_29 0-300.pdf (letöltés ideje: 2019.03.13.)

[7] KovÁCS István: „Olajozás”, szervezett bünözés és prostitúció a 90-es években Magyarországon. Nemzetbiztonsági Szemle, (2015/1.), pp. 114-146.

[8] KovÁcs István: A reglementációs prostitúció és az emberi méltóság kapcsolata, különös tekintettel egy alkotmánybírósági határozatra. Belügyi Szemle, 2016/b/2. szám, pp. 109-126.

[9] KovÁCs István: Die Ermittlung der Förderung der geschäftsmäßigen Prostitution. Hadtudományi Szemle, 2015/3. szám, pp. 177-185.

[10] KovÁcS István: Is the prostitution a threatdanger to a country's (national)security? Nemzetbiztonsági Szemle, V. évfolyam (2017) különszám, pp.12-24.

[11] KovÁCs István: Prostitúció, és prohibíció a mai Magyarországon: avagy miért nem sikerül a rendörségnek a szocializmust levetközni a XXI. században. Létünk, (2018/2.), pp.7-29.

[12] KovÁCS István: The enforcement of crime prevention duties of the Police, in relation of youth - especially juvenile prostitution - and thepractical experiment in Hungary. Hadtudományi Szemle, VIII. évfolyam, (2015) 1. szám pp. 231245.

[13] KovÁCS István: Vezetési funkciók egy helyi rendvédelmi szerv életében. Ellenörzés, mint a kiadott szabályok, és utasitások betartásának (kontroll) feladata. Államtudományi Műhelytanulmányok, II. évfolyam, (2017) 21. szám, pp. 1-30.

[14] KovÁCS István: Vezetési funkciók egy helyi rendvédelmi szerv életében. Tervezés, mint az elérendö cél, és az ahhoz elvezetö tevékenységek meghatározásának folyamata. Müszaki katonai Közlöny, (2018/3), p. 196.

[15] KovÁCs István: Vezetési funkciók egy helyi rendvédelmi szerv életében. Célmeghatározás, vagyis a feladatok kitüzésének, és tisztázásának folyamata. Rendőrégi Tanulmányok, (2018/3.), pp.119-136. 
[16] KovÁCs István: Vezetési stílusok a hivatásos állomány szemével. In: BARÁTH Emőke (szerk.): Rendészettudomány a fiatal kutatók szemével konferenciakötet. 2019. pp.169-179.

[17] KRISKÓ Edina: A rendőrség társadalmi rendeltetése és a rendőrségi kommunikáció.

http://nydi.btk.pte.hu/sites/nydi.btk.pte.hu/files/pdf/Krisko_Edina2013_disszerta cio.pdf, (letöltés ideje: 2019.04.28.)

[18] MARKOVICH Miklós:A szaklap problémája. Rendőr, 1927.07.16. 1.p.

[19] RuMJANCEVAMarina Fedorovna:A XVIII.-XX. század eleji történelmi források /Исторические источники XVIII. - начала XX. века/ pp. 451-466. http://www.historichka.ru/materials/istochnikovedenie/index.html (letöltve: 2019. április 28-án)

[20] SALlaI János: Beköszöntö a Rendörségi Tanulmányok elsö számához (Rendörségi szakfolyóiratok a „Közbiztonság”-tól napjainkig) http://www.bmtt.hu/rtt/assets/letolt/rt/201801/03_Sallai_Janos_Bekoszonto.pdf (letöltve: 2019. április 28-án)

[21] SuBA László: A pénzügyörségi sajtó kezdetei. http://m.ludita.uninke.hu/repozitorium/bitstream/handle/11410/10625/2014_1_tt_subal.pdf?sequen ce $=1$ \&isAllowed=y (letöltve: 2019. április 28-án)

[22] SzABÓ Andrea: A Magyar Királyi Pénzügyőrség rangrendszere 1867-1947. Rendvédelem-történeti Füzetek. XXVII. évf. 54. szám. pp. 107-126.

[23] SzABÓ Andrea: A pénzügyi igazgatás szervezete és képzési rendszere a kiegyezéstöl az I. világháború végéig. In: CZENE-POLGÁR Viktória ZsÁmBOKINÉ FICSKOVSZKY Ágnes (szerk.): Mérföldkövek az adó- és vámigazgatás történetéböl. Magyar Rendészettudományi Társaság Vám és Pénzügyőri Tagozata. Budapest, 2017. pp. 124-137.

[24] SzABÓ Andrea: A pénzügyi igazgatás szervezeti keretei egykor és most a rendészeti feladatok tükrében. In: GAÁL Gyula - HAUTZINGER Zoltán (szerk.): Szent Lászlótól a modernkori magyar rendészettudományig. Pécs, 2017. pp. 351-356.

[25] Ministry of Internal Affairs of the Russian Federation: 1802-1917.https://xn-b1aew.xn--p1ai/history/1802_1917,

[26] Ministry of Internal Affairs of the Russian Federation: A kezdetek kezdete (1802-1917) /У начала начал (1802-1917)/

https://mvd.ru/upload/site1/document_file/0NNNIGno3q.pdf(letöltve: 2019. április 28-án)

[27] TóTH Sándor: A rendörség krónikásai - 140 év laptörténete. In: SzOMOR S. (szerk.): Jubileumi Emlékalbum a 125 éve alakult budapesti detektívtestület tiszteletére. Budapest, 2011. Országos Rendőr-főkapitányság, pp.144-145

[28] VEDó Attila: A Magyar Királyi Csendörség közbiztonsági tevékenységének szervezete és gyakorlata. In: ORBÓK Ákos (szerk.). A hadtudomány és a XXI. század. Budapest, 2016. Doktoranduszok Országos Szövetsége pp. 361-373

Lektorálta: Sallai János Prof. Dr. tanszékvezető egyetemi tanár Nemzeti Közszolgálati Egyetem Rendészettudományi Kar Rendészettörténeti Tanszék sallai.janos@uni-nke.hu 